\title{
Molecular data suggest that Heteromys irroratus bulleri should be recognized as a species-level taxon
}

\author{
María A. Gutiérrez-Costa ${ }^{1}$, Francisco X. González-Cózatl ${ }^{1 *}$, María Magdalena Ramírez-Martínez ${ }^{2}$, \\ LUIS IgNaCio IÑIGUEZ-DÁvalos², AND DUKe S. ROgerS ${ }^{3}$ \\ ${ }^{1}$ Centro de Investigación en Biodiversidad y Conservación, Universidad Autónoma del Estado de Morelos. Avenida Universidad \\ 1001, CP.62209, Cuernavaca, Morelos, México. E-mail: maria.gutierrezcos@uaem.edu.mx (MAG-C), xavier@uaem.mx (FXG-C). \\ ${ }^{2}$ Centro Universitario de la Costa Sur, Universidad de Guadalajara. Avenida Independencia Nacional 151, CP.48900, Autlán, Jalisco, \\ México. E-mail: mmagdalena.ramirez@academicos.udg.mx (MMR-M), liniguez@cucsur.udg.mx (LII-D). \\ ${ }^{3}$ Monte L. Bean Life Science Museum and Department of Biology, Brigham Young University. CP.84602, Provo, Utah, United States. \\ E-mail: duke rogers@byu.edu (DSR). \\ * Corresponding author
}

Recent collecting surveys in the Sierra de Manantlán Biosphere Reserve, Jalisco (México), uncovered the existence of a new population of the Mexican spiny pocket mouse, Heteromys irroratus. Because the subspecies H. i. bulleri and H. i. jaliscensis occur nearby, our objective was to properly determine the taxonomic identity of the novel sample. Also, we evaluate its distinctiveness, both in terms of genetic divergence and phylogenetic placement, relative to other members of $H$. irroratus. Preliminary, we compared external and cranial measurements of recently collected individuals to those reported for representatives of the subspecies of $H$. irroratus occurring close by. In addition, we examined levels of genetic differentiation and phylogenetic relationships, based on sequence data of the Cytochrome $b$, among this population and other members of $H$. irroratus, including an individual from Sierra de Juanacatlán, Jalisco, the type locality of $H$. i. bulleri. Phylogenetic relationships were estimated using Maximum Likelihood and Bayesian Inference methods and levels of genetic divergence were assessed employing Kimura-2-parameters genetic distances. Samples from Sierra de Manantlán and Sierra de Juanacatlán were grouped together in a well-supported haplogroup and genetic distances between them were lower than $<1.02 \%$. Our phylogenetic hypothesis shows that $H$. i. bulleri represents the sister group to all other samples of $H$. irroratus but that, genetically, is a very divergent lineage. Distances values between $H$. i. bulleri to any of the other groups were $>10.05 \%$. Comparison of external and cranial measurements showed that, in average, individuals from Sierra de Manantlán are larger than those of $H$. i. jaliscensis, but more similar in size to $H$. i. bulleri. Our results show that the new population of the Mexican spiny pocket mouse from Sierra de Manantlán belongs to H. i. bulleri. In addition, the phylogenetic separation and the high levels of genetic divergence of $H$. i. bulleri, relative to other members of $H$. irroratus, suggest that the first should be recognized as a species-level taxon. Considering the scarce collecting records of $H$. i. bulleri and the known area of occurrence, that is very restricted, this taxon may warrant special conservation status.

Colectas realizadas recientemente en la Reserva de la Biosfera Sierra de Manantlán, Jalisco (México), permitieron descubrir la existencia de una nueva población del ratón espinoso de abazones mexicano, Heteromys irroratus. Debido a que las subespecies $H$. i. bulleri y $H$. i. jaliscensis ocurren en áreas cercanas, nuestro objetivo fue determinar de forma apropiada la identidad taxonómica de la nueva muestra. Adicionalmente, evaluamos su posible distinción, en términos de su divergencia genética y posición filogenética, en relación con otros miembros de $H$. irroratus. Inicialmente comparamos medidas externas y craneales de los individuos colectados recientemente con las reportadas para representantes de las subespecies de $\mathrm{H}$. irroratus que ocurren en zonas cercanas. Adicionalmente, examinamos niveles de diferenciación genética y las relaciones filogenéticas, basadas en secuencias del gen Citocromo $b$, entre esta población y representantes de otros miembros de $H$. irroratus, incluyendo un individuo de Sierra de Juanacatlán, Jalisco, la localidad tipo de H. i. bulleri. Las relaciones filogenéticas fueron estimadas con métodos de Máxima Verosimilitud e Inferencia Bayesiana y los niveles de divergencia genética fueron evaluados con distancias genéticas corregidas con el modelo de 2 parámetros de Kimura. Las muestras de Sierra de Manantlán y Sierra de Juanacatlán fueron agrupadas en un haplogrupo bien soportado y las distancias genéticas entre ellas fueron menores a $<1.02 \%$. Nuestra hipótesis filogenética indica que $H$. $i$. bulleri representa el grupo hermano de todas las otras muestras de $H$. irroratus, pero que, genéticamente, es un linaje muy divergente. Los valores de distancia entre H. i. bulleri y cualquiera de los otros grupos fueron > $10.05 \%$. La comparación de medidas externas y craneales mostró que, en promedio, los individuos de Sierra de Manantlán son más grandes que los de H. i. jaliscensis y más similares en tamaño a los de $H$. i. bulleri. Nuestros resultados muestran que la nueva población del ratón espinoso de abazones mexicano de Sierra de Manantlán pertenece a H. i. bulleri. Adicionalmente, la separación filogenética y los altos niveles de divergencia genética de $H$. i. bulleri, en relación con otros miembros de $H$. irroratus, sugieren que el primero debe ser reconocido como un taxón con la categoría de especie. Considerando los escasos registros de colecta reportados para $H$. $i$. bulleri y el área de distribución conocida, que es muy restringida, este grupo podría ser candidato a tener un estatus especial de conservación.

Keywords: Cytochrome $b$; genetic divergence; Mexican spiny pocket mouse; phylogeny; valid species.

C 2021 Asociación Mexicana de Mastozoología, www.mastozoologiamexicana.org 


\section{Introduction}

Heteromys irroratus, the Mexican spiny pocket mouse, is a species widely distributed in México and in a small portion of the United States. In México, it is found on the Mexican Plateau and in adjacent areas, and along the main mountain systems and coastal slopes (Genoways 1973; Dowler and Genoways 1978). Altitudinally, $H$. irroratus occurs from sea level, across the coasts of Tamaulipas and Veracruz to nearly 3,050 $\mathrm{m}$ in the highlands of the Sierra Madre de Sur, in México. It can be found mainly in xerophilous scrubland thorny forest, although it also occurs in coniferous and oak forests, and agricultural, and grazing lands (Dowler and Genoways 1978). Currently, seven subspecies are recognized $(H$. irroratus alleni, $H$. i. bulleri, $H$. i. guerrerensis, $H$. i. irroratus, $H$. i. jaliscensis, $H$. i. texensis, and $H$. i. torridus; Genoways 1973; Dowler and Genoways 1978). Of the seven, H. i. bulleri has the most restricted distribution.

Heteromys i. bulleri was described by Thomas (1893) from La Laguna, Sierra de Juanacatlán, Jalisco (México) and is only known from seven specimens collected in the mid-1960's; two from the type locality and five more from the vicinity of Soyatlán del Oro, Jalisco (Genoways 1973). These two localities are approximately $60 \mathrm{~km}$ from each other in the western portion of the state (Figure 1). Although this taxon was described almost 130 years ago, little is known about its natural history.

Recent surveys in the Sierra de Manantlán Biosphere Reserve, in the southwestern portion of Jalisco (México), uncovered the existence of a new population of $H$. irroratus. Although $H$. i. jaliscensis has been reported from localities not far from the Biosphere Reserve and its type locality is about $50 \mathrm{~km}$ distant from Sierra de Manantlán, specimens representing this population did not resemble $H$. i. jaliscensis morphologically. External and cranial measurements of individuals of the new population (Table 1) are larger than the ones reported for individuals of $H$. i. jaliscensis (including samples from its type locality; Genoways 1973). Therefore, considering that H. i. bulleri also occurs in Jalisco, although in a different area, our aim was to assess the subspecific assignment of the Manantlán Biosphere Reserve specimens. Due to the fact that there are only two specimens of $H$. i. bulleri from the type locality (holotype at the British Museum (Natural History), London, United Kingdom, and a topotype at the National Museum of Natural History, United States) and a direct comparison with them was not possible, field work was conducted at the type locality of $H$. i. bulleri to obtain samples to compare with specimens of the new population using Cytochrome $b$ (Cyt $b$ ) sequences. In this study, we report the findings of the molecular identification of the novel samples and their distinctiveness, both in terms of genetic divergence and phylogenetic placement, compared to available sequence data for $\mathrm{H}$. irroratus.

\section{Material and methods}

Eight specimens of the new population of Heteromys irroratus were collected at Las Joyas Scientific Station, located in the Sierra de Manantlán Biosphere Reserve, Municipality of Autlán, Jalisco, México (19³5.443' N, -104 $16.913^{\prime} \mathrm{W}$ ) at 1,957 masl. The area is characterized by pine-oak forest and cloud forest, but spiny pocket mice were captured near a field of Zea diploperennis, an endemic perennial species of teosinte or wild corn. Voucher specimens (preserved in alcohol) were deposited in the Colección Zoológica de Vertebrados, Centro Universitario de la Costa Sur, Universidad de Guadalajara (CVUDG: 1675, 1676, 1710, 1711, 1713, 1714, $1715,1716)$. An additional individual of $H$. irroratus was collected at La Laguna, Sierra de Juanacatlán, Municipality of Mascota, Jalisco, México $\left(20^{\circ} 37.687^{\prime} \mathrm{N},-104^{\circ} 43.752^{\prime} \mathrm{W}\right)$, at 2,050 masl, which represents the type locality of the subspecies $H$. i. bulleri. This specimen was caught in secondary vegetation within a pine-oak forest next to a lake. The voucher specimen (preserved as skin and squeleton) is stored in the Colección de Mamíferos del Centro de Investigación en Biodiversidad y Conservación de la Universidad Autónoma del Estado de Morelos (CMC 3590). Sequences generated as part of this study were uploaded to GenBank and accession numbers are included in Appendix 1. Capture and handling methods followed the animal care and use guidelines of the American Society of Mammalogists (Sikes et al. 2016).

Three external and nine cranial measurements, described by Genoways (1973), were recorded for seven adult specimens of $\mathrm{H}$. irroratus from Sierra de Manantlán (four females and two males) and one adult specimen from Sierra de Juanacatlán (one female; see Table 1). External measurements were obtained from collecting field catalogs, while cranial measurements were recorded by means of a digital caliper with accuracy of $0.1 \mathrm{~mm}$. Discrimination of age categories that represent adult individuals was based on toothrow wear patterns described by Genoways (1973). Measurements were compared to data recorded by Genoways (1973) for individuals of $H$. i. bulleri and $H$.i.jaliscensis occuring near Sierra de Manantlán and Sierra de Juanacatlán. Because

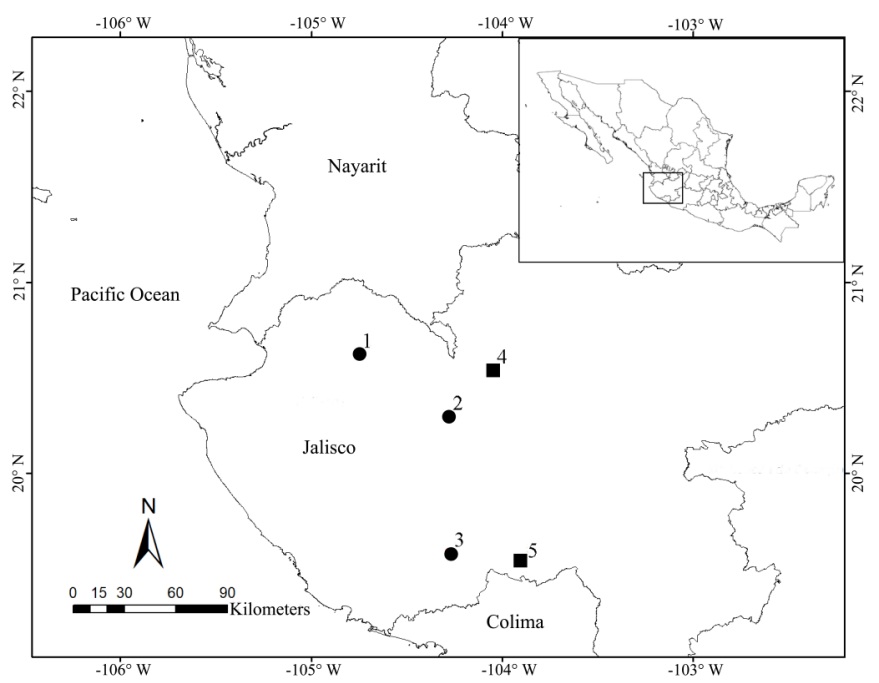

Figure 1. Map illustrating collecting records of Heteromys irroratus bulleri (dots) and H. i. jaliscensis (squares). 1) La Laguna, Sierra de Juanacatlán (H. i. bulleri type locality). 2) Soyatlán del Oro (Genoways 1973). 3) Sierra de Manantlán Biosphere Reserve (current study). 4) Vicinity of Ameca (molecular data from specimens collected at this locality are included in current study as H. i. jaliscensis). 5) Las Canoas (H. i. jaliscensis type locality). 
Genoways (1973) documented that female specimens of H. i. jaliscensis are smaller than males, comparison of measurements among specimens of $H$. irroratus from Sierra de Manantlán and Sierra de Juanacatlán and H. i.jaliscensis were performed by sex. Box plots of external and cranial measurements were generated using STATISTICA v.8.0 (StatSoft 2007).

Total genomic DNA from the newly collected specimens was extracted from liver tissue preserved in $95 \%$ ethanol following the procedure described by Fetzner (1999). Four microliters of DNA were electrophoresed on 1.75 to $2.0 \%$ agarose gels stained with SYBR Green to visualize quality of genomic DNA. MVZ05 and MVZ14 primers (Smith and Patton 1993; Arellano et al. 2005) were used to amplify the Cyt $b$ gene (1140 bp). PCR master mix contained: $1.0 \mu \mathrm{l}$ of template DNA (approximate concentration estimated on a $2 \%$ agarose gel), $1 \mu \mathrm{l}$ of deoxynucleosidetriphosphates (10 $\mathrm{mM}), 5 \mu \mathrm{l}$ of $10 x$ Taq buffer containing $\mathrm{MgCl}_{2}, 1 \mu \mathrm{l}$ of each primer (100 mM concentration), $40.7 \mu$ of distilled water, and $0.3 \mu \mathrm{l}$ of Taq polymerase $(5 \mathrm{U} / \mu \mathrm{l}$; Promega Corp., Madison, Wisconsin) for a $50 \mu \mathrm{l}$ final volume. Standard amplification conditions consisted of 2 to $4 \mathrm{~min}$ at $94^{\circ} \mathrm{C}$ for initial denaturation ( 1 cycle); then, 1 min at $94^{\circ} \mathrm{C}$ for denaturation, $1 \mathrm{~min}$ at $45^{\circ} \mathrm{C}$ for annealing, and $1 \mathrm{~min}$ at $72^{\circ} \mathrm{C}$ for extension (35 cycles); lastly, 5 min at $72^{\circ} \mathrm{C}$ for final extension (1 cycle). Four microliters of PCR-amplified product were assayed by electrophoresis on a $2 \%$ agarose gel. PCR products were purified with a Gene-Clean PCR purification kit (Bio 101, La Jolla, California). Sequencing reactions of purified PCR products were done with the Perkin-Elmer ABI PRISM dye terminator cycle sequencing ready reaction kit (Applied Biosystems, Foster City, California). Excess dye terminator was removed using a Sephadex $50 \mathrm{G}$ solution $(3 \mathrm{~g} / 50 \mathrm{ml}$ $\mathrm{H}_{2} \mathrm{O}$ ). Light- and heavy-strand sequences were determined with an ABI 3100 automated sequencer (Applied Biosystems) housed in the DNA Sequencing Center at Brigham Young University. Final sequences were edited using BioEdit v.7.0.8.0 (Hall 1999). GenBank sequences accession numbers are MT709150, 709151, 709152, 709153, 709154, 709155, 709156, T709157, and (see Appendix 1 for correspondence of accession numbers and voucher collecting information).

New sequences were added to a matrix together with 33 Cyt $b$ sequences of $H$. irroratus available from GenBank and representing the following subspecies: H. i. alleni, H. i. guerrerensis, H. i. irroratus, H. i. jaliscensis, H. i. torridus, and H. i. texensis (first described by Rogers and Vance 2005; Appendix 1). Also, sequences of $H$. pictus accessible from GenBank were downloaded and used as the outgroup in phylogenetic analyses (Appendix 1). Our final matrix included 786 bp of Cyt $b$.

Sequence alignment was done with BioEdit v.7.0.8.0 (Hall 1999). Hypotheses concerning phylogenetic relationships among sequences were estimated using Maximum Likelihood (ML) and Bayesian Inference (BI) employing IQTREE v.1.6.10 (Kalyaanamoorthy et al. 2017; Nguyen et al. 2015) and MrBayes v.3.2.2 (Ronquist et al. 2012) on XSEDE, respectively. The model of DNA evolution most appropriate for our data was selected using jModelTest2 on XSEDE (Darriba et al. 2012) under the Bayesian information criterion $(\mathrm{BIC})$. To assess if data needed to be partitioned by codon position, we employed ModelFinder (Kalyaanamoorthy et al. 2017). The transition model 2 with invariable sites and rate heterogeneity $\left(\mathrm{TIM}_{2}+\mathrm{I}+\mathrm{G} 4\right.$; Tamura and Nei 1993) was determined as the best-fit model of nucleotide substitution $(\pi \mathrm{A}=0.288, \pi \mathrm{C}=0.248, \pi \mathrm{G}=0.142$, and $\pi \mathrm{T}=0.323 ; \mathrm{rAC} / \mathrm{AT}$ $=1.000 / 1.000, \mathrm{rCG} / \mathrm{GT}=1.000 / 1.000 ; \mathrm{I}=0.475 ; a=0.224)$, and the data were not partitioned. For the ML analysis, tree searches were performed employing IQ-TREE default search parameters. Branch support was assessed through ultrafast bootstrap (UB) with 1,000 replicates (Hoang et al. 2018). For the $\mathrm{BI}$ analyses, runs were specified with four of MCMC chains and $50,000,000$ generations, with a sample frequency of 1,000 generations. This resulted in 50,000 samples from the posterior probability (PP) distribution. Burn-in value was set to 10,000 . This resulted in 50,000 samples and the burn-in value was set to 10,000 . The posterior probability (pP) was computed for individual branches by constructing a majority-rule consensus with the trees not discarded as burn-in. Once the main phylogenetic haplogroups were identified, uncorrected (p-distances) and Kimura-2-parameters (K2P; Kimura 1980) genetic distances were calculated employing Mega v.7.0.3 (Kumar et al. 2016). The former genetic measurement is provided for further comparison to other mammal taxa. The latter genetic distance was compared between selected sequences of $H$. irroratus since it has been widely used to compare levels of DNA sequence divergence in mammals under the Genetic Species Concept framework (Bradley and Baker 2001; Baker and Bradley 2006).

\section{Results}

External and cranial measurements among specimens of the new population of $H$. irroratus from Sierra de Manantlán and individuals of $H$. i. jaliscensis showed overlap in the ranges displayed by most variables for both females and males (Table 1; Figures 2, 3). On average, the four adult females of $H$. irroratus from Sierra de Manantlán are larger than the females of $H$. i. jaliscensis. This is particularly evident for three external measurements (total length, length of tail, length of hind foot; Figures 2a-c) and five cranial variables (greatest length of skull, mastoid breadth, length of nasals, length of maxillary toothrow, depth of braincase; Table 1; Figures 2d-j). The two adult males from Sierra de Manantlán showed larger mean values for three cranial measurements (mastoid breadth, length of nasals, and depth of braincase) compared to males of $H$. i. jaliscensis (Table 1; Figures 3f-j). The only adult female specimen of $H$. irroratus from Sierra de Juanacatlán, also displayed larger values for all three external and seven cranial measurements compared to average values depicted by females of $H$. i. jaliscensis (Table 1; Figures 2a-j). Mean lengths of the adult females of $H$. irroratus from Sierra de Manantlán and Sierra de Juanacatlán were more similar to the mean measurements of specimens of $H$. i. bulleri reported by 


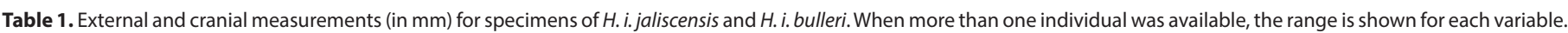
Mean values are in parentheses. Sierra de Manantlán (SM), Sierra de Jaunacatlán (SJ).

Genoways (1973)

This study

H. i. jaliscensis

H. i. bulleri*

H. i. bulleri SM

H. i. bulleri SJ

External and cranial measurements

Females Males

$(n=51) \quad(n=38)$

$(n=2)$

Total length

207.0-251.0 (226.9)

212.0-272.0 (238.3)

$245.0-250.0(247.4)^{* *}$

$226.0-255.0(245.5) \quad 228.0-249.0(238.0)$

249.0

Length of tail

101.0-131.0 (114.1)

103.0-140.0 (118.7)

$127.0-128.0(127.4)^{* *}$

$113.0-134.0(125.0)$

125.0

128.0

Length of hind foot

$\begin{array}{cc}25.0-30.0(27.3) & 26.5-32.0(28.9) \\ 30.1-33.2(31.6) & 30.4-35.1(32.6) \\ 7.2-8.6(7.8) & 7.2-9.0(8.0) \\ 13.8-14.7(14.2) & 13.8-15.9(14.8) \\ 11.0-13.5(12.1) & 11.4-13.4(12.3) \\ 12.9-14.9(13.8) & 12.2-15.7(13.7) \\ 4.4-5.4(4.8) & 4.8-5.8(5.3) \\ 8.2-9.1(8.6) & 8.2-9.3(8.7) \\ 7.3-9.5(8.3) & 7.9-9.8(8.7) \\ 2.5-4.4(3.2) & 3.0-4.4(3.6)\end{array}$

$27.0-32.0(29.3)^{* *}$
$33.5-34.1(33.8)$
$8.2-8.7(8.5)$
$14.8-15.5(15.1)$
$13.2-14.1(13.6)$
$15.3^{* *}(15.3)$
$5.9-6.0(5.9)$
$9.4-10.0(9.7)^{* *}$
$5.4-8.0(6.7)$
$3.2-3.9(3.6)$

$26.0-32.0(29.2)$
$31.8-33.5(32.7)$
$7.6-8.1(8.0)$
$14.4-15.4(14.8)$
$13.2-14.6(14.1)$
$12.8-14.4(13.9)$
$5.5-5.9(5.6)$
$9.2-9.8(9.5)$
$7.4-7.8(7.8)$
$3.7-4.2(3.9)$

$25.9-30.0(27.8)$
33.7
$7.7-7.9(7.8)$
$14.8-15.3(15.0)$
$14.4-14.6(14.5)$
$14.1-14.5(14.3)$
$5.2-5.3(5.2)$
$9.4-9.7(9.5)$
7.4
3.9

Mastoid breadth

Length of rostrum

Length of maxillary toothrow

Depth of braincase

Interparietal width

terparietal length

*Samples included two adult females from La Laguna, Sierra de Juanacatlán (type locality) and one adult female from Soyatlán del Oro.

**Data preceded by two asterisks were recorded for only two specimens.

Genoways (1973), particularly two external variables (total length and length of tail; Table 1; Figures 2a, 2b) and one cranial measurement (length of nasals; Table 1; Figure 2g).

Phylogenies derived from ML (Figure 4) and $\mathrm{BI}$ (not shown) were highly congruent. Sequences from Sierra de Manantlán grouped together with high nodal support (UB $=91$ and $\mathrm{PP}=0.99)$. In turn, the sequence from Sierra de Juanacatlán (CMC 3590) joined those sequences from Sierra de Manantlán forming a strongly supported haplogroup (UB $=100$ and $P P=1.0$; Figure 4). The H. i. bulleri haplogroup was positioned as a divergent sister group to the other sequences of $H$. irroratus. The remaining sequences of $H$. irroratus formed a monophyletic group with strong nodal support values (84 / 0.99). This clade contained representatives of the other six subspecies of $H$. irroratus (alleni, guerrerensis, irroratus, jaliscensis, texensis, and torridus). Sequences of each subspecies formed separate haplogroups, with the exception of $H$. i. alleni. Sequences representing this subspecies split into two independent lineages, H. i. alleni (1) and $H$. i. alleni (2). Although two divergent lineages were also found within $\mathrm{H}$. i. texensis, they are sister to each other. In summary, we identified a total of eight haplogroups within $\mathrm{H}$. irroratus.

Pairwise K2P genetic distances (Kimura 1980) between localities 1 and 3 of $H$. i. bulleri (Figure 1) ranged between $0.63 \%$ and $1.02 \%$ with a mean of $0.84 \%$ (Table 2 ). In contrast, the mean K2P genetic distance between individuals of $H$. i. bulleri and the other haplogroups ranged from $10.05 \%$ (H. i. jaliscensis) to $11.94 \%$ (H. i. irroratus). Among all haplogroups of $H$. irroratus, except $H$. i. bulleri, K2P distances ranged between $1.59 \%$ (H. i. guerrerensis-H. i. irroratus) and $8.34 \%$ (H. i. jaliscensis-H. i. alleni (2); Table 2).

Table 2. Pairwise Kimura-2-parameter distances (below the diagonal) and p-distances (above the diagonal), between samples of Heteromys irroratus based on 786 bp of the Cytochrome $b$ gene.

\begin{tabular}{|c|c|c|c|c|c|c|c|c|}
\hline Taxon & H.i. irroratus & H. i. texensis & H.i. alleni (1) & H. i. jaliscensis & H.i. alleni (2) & H.i.guerrerensis & H.i.torridus & H.i.bulleri \\
\hline H.i. irroratus & & 0.0694 & 0.0635 & 0.0705 & 0.0734 & 0.0157 & 0.0564 & 0.1079 \\
\hline H.i. texensis & 0.0742 & & 0.0407 & 0.0505 & 0.0744 & 0.0637 & 0.0405 & 0.1016 \\
\hline H.i. alleni (1) & 0.0675 & 0.0423 & & 0.0364 & 0.0657 & 0.0619 & 0.0233 & 0.0930 \\
\hline H. i. jaliscensis & 0.0751 & 0.0527 & 0.0375 & & 0.0776 & 0.0636 & 0.0449 & 0.0927 \\
\hline H. i. alleni (2) & 0.0789 & 0.0800 & 0.0701 & 0.0834 & & 0.0725 & 0.0623 & 0.1049 \\
\hline H.i.guerrerensis & 0.0159 & 0.0678 & 0.0659 & 0.0674 & 0.0780 & & 0.0534 & 0.1025 \\
\hline H.i. torridus & 0.0595 & 0.0421 & 0.0238 & 0.0467 & 0.0662 & 0.0563 & & 0.0973 \\
\hline H.i.bulleri & 0.1194 & 0.1116 & 0.1013 & 0.1005 & 0.1160 & 0.1129 & 0.1064 & \\
\hline
\end{tabular}



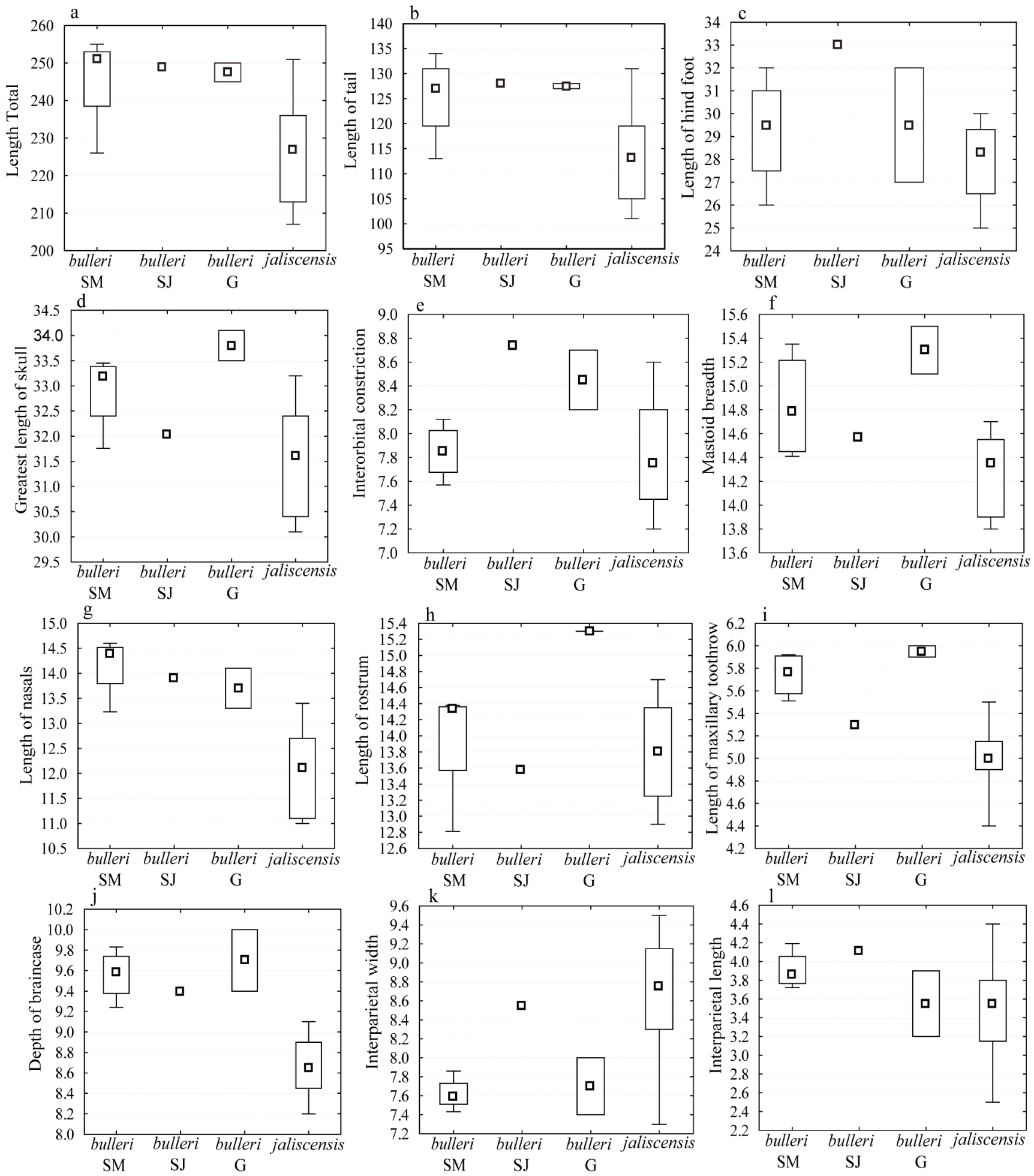

Figure 2. Box plots of female measurements of individuals of H. i. bulleri from Sierra de Manantlán (bulleri SM), H. i. bulleri from Sierra de Juanacatlán (bulleri SJ), H. i. bulleri from Genoways (1973; bulleri G), and H. i. jaliscensis from Genoways (1973; jaliscensis). Median (small squares), $25 \%$ to $75 \%$ confidence interval (rectangles), and minimum and maximum values (whiskers).

\section{Discussion}

This study focuses on the molecular taxonomic identification of individuals of a new populations of $H$. irroratus from Sierra de Manantlán Biosphere Reserve, a locality in southern Jalisco (México), and its phylogenetic placement within this group. Our initial identification assessment involved the comparison of external and cranial measurements to H. i. jaliscensis and H. i. bulleri, two subspecies of this taxon occurring not far from this new collecting locality. Yet, ranges of measurements between adult females from Sierra de Manantlán and those of $H$. i.jaliscensis overlap, the former are on average larger than the latter (Table 1, Figures 2, 3). Although differences in length between males from Sierra de Manantlán and $H$. i. jaliscensis were not evident for most variables, specimens from Sierra de Manantlán displayed larger mastoid breadth, length of nasals, length of rostrum, 

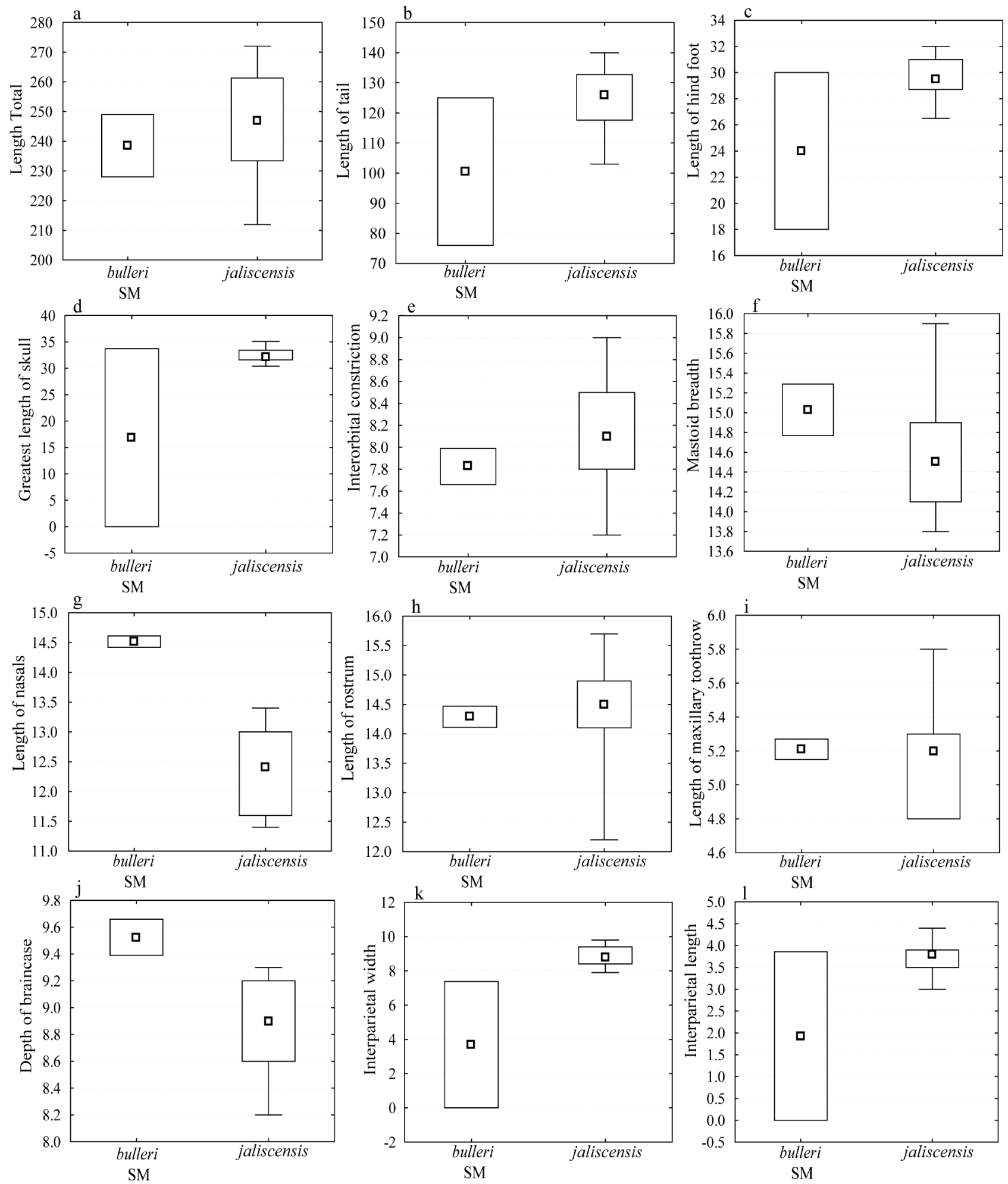

Figure 3. Box plots of male measurements of individuals of H. i. bulleri from Sierra de Manantlán (bulleri SM) and H. i. jaliscensis from Genoways (1973; jaliscensis). Median (small squares), $25 \%$ to $75 \%$ confidence interval (rectangles), and minimum and maximum values (whiskers).

and depth of braincase. On the other hand, measurements of females from Sierra de Manantlán were similar to those of H. i. bulleri reported by Genoways (1973). These results, principally the data recorded for females, preliminary suggest that specimens of the new population of $H$. irroratus from Sierra de Manantlán were not representatives of $H$. $i$. jaliscensis, but rather, represented the subspecies $H$. $i$. bulleri. In addition, the female specimen collected at the type locality of $H$. i. bulleri (La Laguna, Sierra de Juanacatlán), exhibited measurements that better agree with those reported for H. i. bulleri than for H. i. jaliscensis (Genoways, 1973 Genoways 1973), suggesting that this individual also belongs to the former taxon. This is in agreement with the findings reported by Genoways (1973) who concluded that H. i. bulleri can be discriminated from H. i. jaliscensis (and other subspecies) by its larger external and cranial size. 
Although, it was not possible to make a comparison with type specimens of $H$. i. bulleri, color patterns (fresh pelage) of the individual collected at the type locality (upperparts gray mixed with black and ochraceous hairs; sides with a pale ochraceous line; underparts white; feet white; ears dusky with a white edge; tail bicolor, brown above and white below) match those described for $H$. i. bulleri (Thomas 1893; Goldman 1911), supporting the assignment of this specimen to this taxon. Although Heteromys pictus could also occur at the type locality of $H$. i. bulleri, it can be distinguished from $\mathrm{H}$. irroratus by the presence of six plantar tubercles on each hind foot (compared to five plantar tubercles displayed by H. irroratus; Genoways 1973) and overall smaller size. The fact that all the specimens of Heteromys from Sierra de Manantlán and Sierra de Juanacatlán collected for our study possess five plantar tubercles on each hind foot, supports the hypothesis they are representatives of $H$. irroratus.

When comparing Cyt $b$ sequence data between the sample from Sierra de Juanacatlán (type locality of $H$. i. bulleri) to any of the individuals from Sierra de Manantlán, the genetic distance values were $<1.02 \%$ (mean $0.84 \%$ ), lower than the upper bound (1.8\%) of the intrasubspecific range reported by Bradley and Baker (2001) for Cyt $b$ in rodents. This suggests a close affinity between individuals from the Sierras de Juanacatlán and Manantlán and supports that they represent the same subspecies. This hypothesis is also supported by the fact that all these sequences formed a single haplogroup with strong nodal support. Since the sample from Sierra de Juanacatlán represents the type locality of $H$. i. bulleri, we propose that specimens from the Sierra de Manantlán also represent $H$. i. bulleri. Certainly, confirmation of this findings would be desirable by analyzing additional data such as nuclear markers and morphological features.

Although we did not have molecular data for H. i. jaliscensis from its type locality (Las Canoas, Jalisco) to confirm that specimens from Sierra de Manantlán do not belong to that subspecies, we included representatives of $H$. i. jaliscensis from Ameca, Jalisco. Samples of $H$. irroratus from these two localities (Las Canoas and Ameca), were analyzed morphologically by Genoways (1973) and regarded as the same subspecies. The levels of genetic differentiation between $H$. i. jaliscensis and specimens from Sierra de Manantlán were comparatively high (10.05\%; Table 2$)$, supporting the hypothesis that they represent distinct subspecies.

Our phylogenetic hypothesis places $H$. i. bulleri as the sister group to all other forms of $H$. irroratus (Figure 4). The reciprocal monophyly of these two clades was well supported $(H$. i. bulleri $=100 / 1.0$; other $H$. irroratus $=84 / 0.98)$. Likewise, the high degree of genetic divergence among sequences of these two clades was documented with K2P;

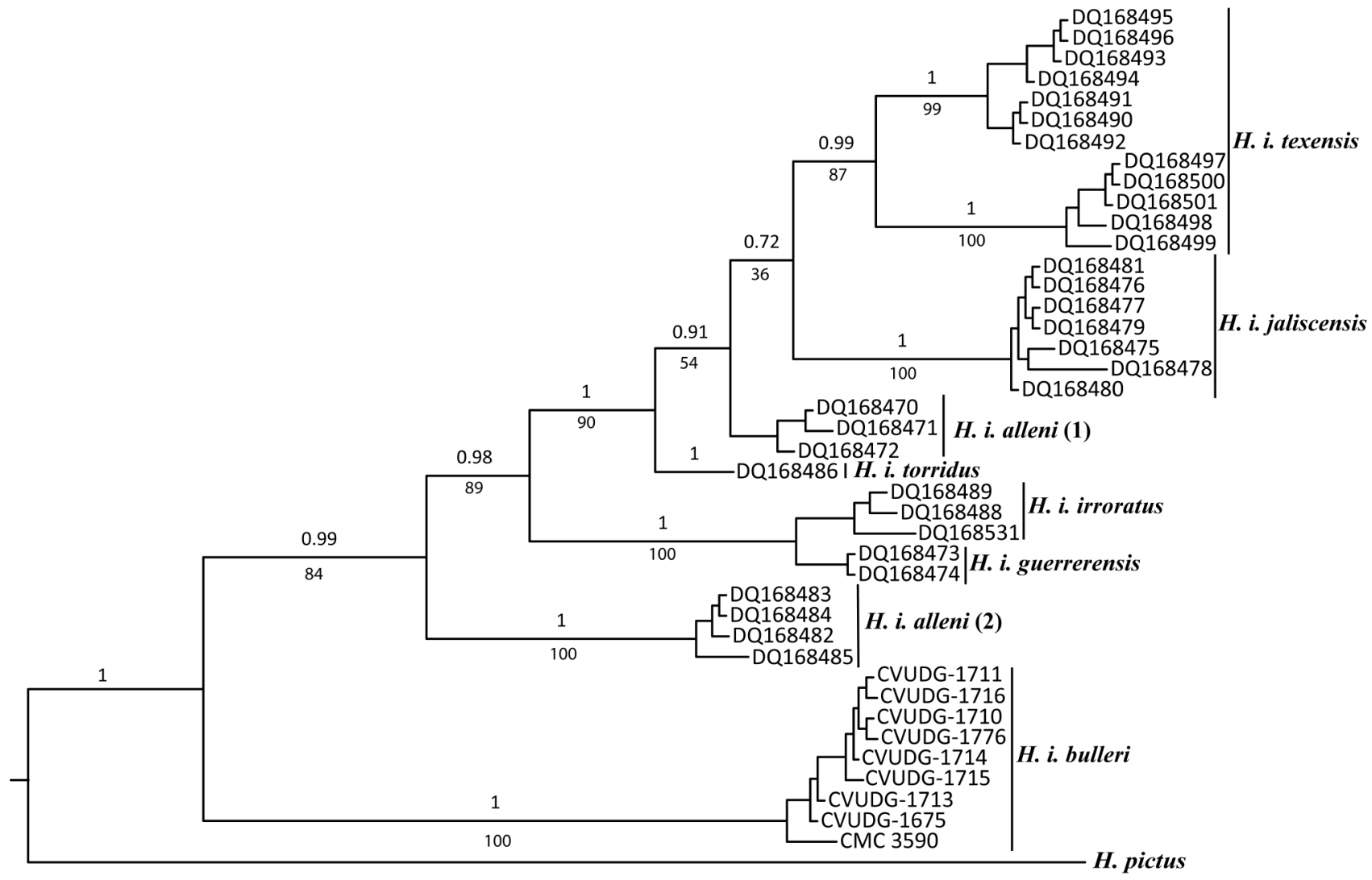

0.02

Figure 4. Maximum likelihood phylogenetic tree of Heteromys irroratus sequences based on 786 bp of the Cytochrome $b$ gene (InL $=-3357.567)$. Posterior probability estimates are shown above branches and bootstrap values are below branches. 
in any pairwise comparison between these two groups, genetic distances exceeded $10 \%$. This level of Cyt $b$ genetic differentiation can be indicative of distinct species (Bradley and Baker 2001; Baker and Bradley 2006).

Although H. i. bulleri is currently recognized as a subspecies (Genoways 1973), it was originally described as a species by Thomas (1893:330) because it had a "skull strong and stoutly built, differing mainly from that of $H$. alleni in its much greater size, and from that of $H$. irroratus by its differently shaped interparietal". The specific status of $H$. $i$. bulleri was supported by Goldman (1911:62) who wrote: "In external appearance it resembles alleni and jaliscensis, but the cranial characters, especially the decidedly smaller size and more triangular shape of the interparietal, distinguish it from either". Genoways (1973), based on a morphological analysis of all known forms of the Mexican spiny pocket mouse, found that samples of $H$. i. bulleri possessed deeper braincases, compared to other groups of $\mathrm{H}$. irroratus. Heteromys i. bulleri also was separated from all other samples of $\mathrm{H}$. irroratus in a Principal Component Analysis. In addition, a UPGMA phenogram showed that, at least for the sample from Soyatlán del Oro, is quite distinct from the rest of samples representing the Mexican spiny pocket mouse. Finally, Genoways (1973:106) observed that "the small size of the interparietal is rather unique" for bulleri, although he pointed out that this feature was shared with a population of H. i. alleni from Michoacán. However, he concluded that, due to the high variation of the shape and size of the interparietal bone in $\mathrm{H}$. irroratus and other species in the genus, specific distinction of bulleri should not be based on that single character, and therefore, he relegated it to the subspecific level.

Although our molecular data represent a portion of a single mitochondrial gene, the level of genetic differentiation documented by this marker for $H$. i. bulleri relative to other samples of $H$. irroratus, suggest that it represents a distinct species-level taxon. However, we believe that additional data (both molecular and morphological) are necessary to further test the specific status of this taxon.

The fact that $H$. i. bulleri should be considered a distinct species supports previous views suggesting that $H$. irroratus is a species complex containing some species-level lineages (Rogers and Vance 2005). It has been demonstrated that individuals of $H$. irroratus from near Pátzcuaro, Michoacán, México (represented by our H. i. alleni (2) haplogroup; Figure 2) were genetically distinct and can be considered as a candidate species. Also, it was concluded that populations of $H$. irroratus from Guerrero and Oaxaca are genetically differentiated and may represent a second candidate species (Rogers and Vance 2005).

Since its description in 1893, only 16 specimens of $H$. $i$. bulleri have been collected: two reported at the time of its description, five more collected between 1956 and 1966, and nine more reported in this study were trapped between 2014 and 2020. The scarce number of voucher specimens collected in almost 130 years suggests that either the trap- ping efforts have been insufficient to properly sample it or this taxon is uncommon. The Sierra de Manantlán is a new locality for $H$. i. bulleri and represents a range extension of about $125 \mathrm{~km}$ southeast from the type locality and $80 \mathrm{~km}$ south from Soyatlán del Oro. Given that H. i. bulleri is distinctive molecularly and morphologically and coupled with its restricted distribution, it is crucial to pay attention to conservation issues surrounding this taxon.

\section{Acknowledgments}

Weacknowledge financial support from the Consejo Nacional de Ciencia y Tecnología (CONACYT No. 623012; to MAG-C) and the Department of Biology, Brigham Young University (to DSR). Collecting permits for fieldwork were issued by the Secretaría de Medio Ambiente, Recursos Naturales y Pesca (SEMARNAT) to MMR-M (SGPA/DGVS/8540/19) and FXG-C (SGPA/DGVS713602/19). Special thanks to the Dirección de la Reserva de la Biósfera Sierra de Manantlán for its authorization to collect in that protected area. We also thank the following people for their assistance in the field and laboratory work: E. Arellano, D. D. Cruz, N. I. López, and N. Lewis-Rogers, and two anonymous reviewers who kindly read drafts of this work and supplied valuable comments.

\section{Literature cited}

Arellano, E., F. X. González-Cozátl, and D. S. Rogers. 2005. Molecular systematics of the Middle American harvest mice Reithrodontomys (Muridae), estimated from mitochondrial cytochrome $b$ gene sequences. Molecular Phylogenetics and Evolution 37:529-540.

BakeR, R. J., AND R. D. Bradley. 2006. Speciation in mammals and the genetic species concept. Journal of Mammalogy 87:643-662.

Bradley, R. D., and R. J. Baker. 2001. A test of the genetic species concept: Cytochrome-b sequences and mammals. Journal of Mammalogy 82:960-973.

Darriba, D., G. L. Taboada, R. Doallo, and D. Posada. 2012. jModelTest 2: more models, new heuristics and parallel computing. Nature Methods 9:772.

Dowler, R. C., AND H. H. Genoways. 1978. Liomys irroratus. Mammalian Species 82:1-6.

FetzNeR, J. W., JR. 1999. Extracting high quality DNA from shed reptile skins: a simplified method. Biotechniques 26:1052-1054.

Genoways, H. H. 1973. Systematics and evolutionary relationships of spiny pocket mice, genus Liomys. Special Publications The Museum Texas Tech University 5:1-368.

Goldman, E. A. 1911. Revision of the spiny pocket mice (genera Heteromys and Liomys). North American Fauna 34:1-70.

HaLL, T. 1999. BioEdit: a user-friendly biological sequence alignment editor and analysis program for Windows 95/98/ NT. Nucleic Acids Symposium Series 41:95-98.

Hoang, D. T., O. Chernomor, A. von Haeseler, B. Q. Minh, and L. S. VINH. 2018. UFBoot2: Improving the ultrafast bootstrap approximation. Molecular Biology and Evolution 35:518-522.

Kalyaanamoorthy, S., B. Q. Minh, T. K. F. Wong, A. von Haeseler, AND L. S. Jermin. 2017. ModelFinder: Fast model selection for accurate phylogenetic estimates. Nature Methods 14:587-589. 
KımURA, M. 1980. A simple method for estimating evolutionary rates of base substitutions through comparative studies of nucleotide sequences. Journal of Molecular Evolution 16:111-120.

Kumar, S., G. Stecher, and K. Tamura. 2016. MEGA7: Molecular evolutionary genetics analysis version 7.0 for bigger datasets. Molecular Biology and Evolution 33:1870-1874.

Nguyen, L. T., H. A. Schmidt, A. von Haeseler, and B. Q. Minh. 2015. IQ-TREE: A fast and effective stochastic algorithm for estimating maximum likelihood phylogenies. Molecular Biology and Evolution 32:268-274.

Rogers, D. S., ANd V. L. Vance. 2005. Phylogenetic relationships among spiny pocket mice (Liomys: Family Heteromyidae): Analysis of cytochrome $b$ based on multiple heuristic approaches. Journal of Mammalogy 86:10851094.

Ronquist, F., M. Teslenko, P. van der Mark, D. L. Ayres, A. Darling, S. Höhna, B. Larget, L. Liu, M. A. Suchard, and J. P. HuelsenBECK. 2012. MRBAYES 3.2: Efficient Bayesian phylogenetic inference and model selection across a large model space. Systematic Biology 61:539-542.

Sikes, R. S., And the Animal Care and Use Committee of the AmeriCan Society of Mammalogists. 2016 Guidelines of the American Society of Mammalogists for the use of wild mammals in research and education. Journal of Mammalogy 97:663-688.

Smith, M., ANd J. Patton. 1993. The diversification of South American murid rodents: evidence from mitochondrial DNA sequence data for the akodontine tribe. Biological Journal of the Linnaean Society 50:149-177.

StatSoft, Inc. 2007. STATISTICA (data analysis software system). version 8.0. wWw.statsoft.com.

Tamura, K., AND M. Nel. 1993. Estimation of the number of nucleotide substitutions in the control region of mitochondrial DNA in humans and chimpanzees. Molecular Biology and Evolution 10:512-526.

Tномаs, 0. 1893. Description of two new "pocket-mice" of the genus Heteromys. The Annals and Magazine of Natural History 11:329-332.

\section{Associated editor: Mónica Díaz}

Submitted: July 28, 2020; Reviewed: August 8, 2020;

Accepted: January 18, 2020; Published on line: January 22, 2021. 


\section{Appendix 1}

Specimens of Mexican Heteromys used in the molecular analysis listed by subspecies, state, collecting locality (specific locality, elevation, and geographic coordinates), museum voucher (acronym and number), and GenBank accession number (DQ series first reported by Rogers and Vance 2005). Museum abbreviations are as follows: Brigham Young University (BYU); Colección de Mamíferos at Centro de Investigación en Biodiversidad y Conservación, Universidad Autónoma del Estado de Morelos (CMC); Carnegie Museum of Natural History (CM); Biodiversity Research and Teaching Collection, Texas A\&M University (TCWC); Colección Zoológica de Vertebrados, Centro Universitario de la Costa Sur, Universidad de Guadalajara (CVUDG).

\begin{tabular}{|c|c|c|c|c|}
\hline Taxon (Haplogroup) & State & Collecting locality & Museum Voucher & $\begin{array}{c}\text { GenBank Accession } \\
\text { No. }\end{array}$ \\
\hline \multirow{3}{*}{ H. i. alleni (1) } & \multirow{3}{*}{ Durango } & \multirow{3}{*}{25 km E, 22 km S Vicente Guerrero, Municipio Vicente Guerrero, 1,950 m (23.713, -104.000) } & BYU 15765 & DQ 168470 \\
\hline & & & BYU 15766 & DQ 168471 \\
\hline & & & BYU 15767 & DQ 168472 \\
\hline \multirow{4}{*}{ H. i. alleni (2) } & \multirow{4}{*}{ Michoacán } & \multirow{4}{*}{10 km S (by road) Pátzcuaro, 2,200 m (19.470, -101.609) } & BYU 16051 & DQ 168482 \\
\hline & & & BYU 16052 & DQ 168483 \\
\hline & & & BYU 16053 & DQ 168484 \\
\hline & & & BYU 16055 & DQ 168485 \\
\hline \multirow{8}{*}{ H. i. bulleri } & \multirow{8}{*}{ Jalisco } & \multirow{8}{*}{ Estación Científica las Joyas, Reserva de la Biósfera Sierra de Manantlán, 1,957 m (19.586, -104.2743) } & CVUDG 1675 & MT 709150 \\
\hline & & & CVUDG 1713 & MT 709151 \\
\hline & & & CVUDG 1711 & MT 709152 \\
\hline & & & CVUDG 1710 & MT 709153 \\
\hline & & & CVUDG 1714 & MT 709154 \\
\hline & & & CVUDG 1715 & MT 709155 \\
\hline & & & CVUDG 1716 & MT 709156 \\
\hline & & & CVUDG 1676 & MT 709157 \\
\hline H. i. bulleri & Jalisco & La Laguna, Sierra de Juanacatlán, 2,050 m (20.499, -103.145) & CMC 3590 & MT 709149 \\
\hline \multirow{2}{*}{ H. i. guerrerensis } & \multirow{2}{*}{ Guerrero } & \multirow{2}{*}{$6.1 \mathrm{~km} \mathrm{SW}$ (by road) Omiltemi, 2,490 m (17.549, -99.721) } & BYU 20646 & DQ 168473 \\
\hline & & & CMC 399 & DQ 168474 \\
\hline \multirow{2}{*}{ H. i. irroratus } & \multirow{2}{*}{ Oaxaca } & \multirow{2}{*}{ El Polvorín, 5.3 km turn off Lachao Viejo (by road), 1,735 m (16.453, -97.002) } & CMC 408 & DQ 168488 \\
\hline & & & CMC 410 & DQ 168489 \\
\hline \multirow{2}{*}{ H.i. irroratus } & \multirow{2}{*}{ Oaxaca } & \multirow{2}{*}{18.5 km S (by road) Sola de Vega, 2,175 m (16.199, -97.134) } & BYU 20652 & DQ 168487 \\
\hline & & & CMC 419 & DQ 168531 \\
\hline \multirow{7}{*}{ H. i. jaliscensis } & \multirow{7}{*}{ Jalisco } & \multirow{7}{*}{24 km W (by road) Ameca, 1,470 m (20.522, -104.076) } & BYU 16044 & DQ 168481 \\
\hline & & & BYU 16045 & DQ 168475 \\
\hline & & & BYU 16046 & DQ 168476 \\
\hline & & & BYU 16047 & DQ 168477 \\
\hline & & & BYU 16048 & DQ 168478 \\
\hline & & & BYU 16049 & DQ 168479 \\
\hline & & & BYU 16050 & DQ 168480 \\
\hline \multirow{4}{*}{ H. i. texensis } & \multirow{4}{*}{$\begin{array}{l}\text { San Luis } \\
\text { Potosí }\end{array}$} & \multirow{4}{*}{ Rancho Plan de la Laja, Xilitlilla, 6 km W Xilitla, Municıpio Xilitla, 785 m (21.355, -99.031) } & BYU 15265 & DQ 168493 \\
\hline & & & BYU 15266 & DQ 168494 \\
\hline & & & BYU 15267 & DQ 168495 \\
\hline & & & BYU 15268 & DQ 168496 \\
\hline \multirow{3}{*}{ H. i. texensis } & & & TCWC 41724 & DQ 168490 \\
\hline & Puebla & 3.5 miles SW Xicotepec de Juárez $(20.279,-97.964)$ & CM 70450 & DQ 168491 \\
\hline & & & CM 70451 & DQ 168492 \\
\hline & & & TCWC 42044 & DQ 168497 \\
\hline & & & TCWC 42045 & DQ 168498 \\
\hline H.i.texensis & Tamaulipas & 2.2 miles N Soto la Marina $(23.814,-98.189)$ & TCWC 42046 & DQ 168499 \\
\hline & & & TCWC 42047 & DQ 168500 \\
\hline & & & TCWC 42048 & DQ 168501 \\
\hline H. i. torridus & Morelos & Cuernavaca, 2,210 m (18.986, -99.236) & CMC 404 & DQ 168486 \\
\hline H. pictus & Oaxaca & El Polvorín, 5.3 km turn off Lachao Viejo (by road), 1,735 m $(16.453,-97.002)$ & BYU 20656 & DQ 168534 \\
\hline
\end{tabular}

